Editorial

\title{
The human and social dimensions of invasion science and management
}

\section{A R T I C L E I N F O}

\section{Keywords:}

Actors

Attitudes

Beliefs

Biological invasions

Conflicts of interest

Environmental management

Perceptions

Social-ecological systems

Stakeholder engagement

\begin{abstract}
A B S T R A C T
Biological invasions are a leading cause of global environmental change given their effects on both humans and biodiversity. Humans introduce invasive alien species and may facilitate their establishment and spread, which can alter ecosystem services, livelihoods, and human well-being. People perceive the benefits and costs of these species through the lens of diverse value systems; these perspectives influence decisions about when and where to manage them. Despite the entanglement of humans with invasive alien species, most research on the topic has focused on their ecological aspects. Only relatively recently have the human and social dimensions of invasions started to receive sustained attention in light of their importance for understanding and governing biological invasions. This editorial draws on contributions to a special issue on the "Human and Social Dimensions of Invasion Science" and other literature to elucidate major trends and current contributions in this research area. We examine the relation between humans and biological invasions in terms of four crosscutting themes: (1) how people cause biological invasions; (2) how people conceptualise and perceive them; (3) how people are affected - both positively and negatively - by them; and (4) how people respond to them. We also highlight several ways in which research on the human and social dimensions of invasion science improves understanding, stakeholder engagement, and management.
\end{abstract}

\section{Introduction}

Invasive alien species (IAS) are a major driver of global change, affecting humans and the environment. Within the field of invasion science, as well as within other fields of environmental management and conservation, it is increasingly being recognised that studying the social domain is needed to build defendable and sustainable management solutions (Robbins, 2001; Le Maitre et al., 2004; García-Llorente et al., 2008; Decker et al., 2012; Head et al., 2015; Bennett et al., 2017a; b; Christie et al., 2017; Head, 2017; Kueffer, 2017; Backstrom et al., 2018; Teel et al., 2018). This is because the issues associated with IAS, as in most environmental change and management issues, are embedded within a suite of social-ecological systems (Thomas, 1956; Redman et al., 2004; Ostrom, 2009). Therefore, social and ecological complexities need further research to enhance our understanding and help us improve environmental management and build resilience (Berkes et al., 2000; Head, 2017). This has led to calls for increased research within the social domain along with more inter- and trans-disciplinary collaborated research and a shift from invasion biology to more holistic invasion science (Richardson, 2011; Kueffer, 2013; Wilson et al., 2016; Vaz et al., 2017a).

Humans and society are fundamentally involved with biological invasions in multiple ways, from initial introduction, to recognition and management - a point that was acknowledged by early researchers such as Elton (1958), Harlan and De Wet (1965) and Crosby (1986). Although research into the biological aspects of IAS grew quickly from the late 1980s, social science and humanities-related research concerning IAS has only emerged in the last two to three decades (e.g., Symanski, 1994; Peretti, 1998; Symanski, 1994; Robbins, 2001; Mitman, 2004; Robbins, 2004a,b; Richardson, 2011; Vaz et al., 2017a), with major syntheses in the form of edited volumes appearing much more recently (Dobson et al., 2013; Rotherham and Lambert, 2011; Farwley and McCalman, 2014). Research in this area is still less common than work on the ecological aspects of biological invasions (Vaz et al., 2017a; Abrahams et al. this issue).

Early work on the human and social domain focused mainly on humans as catalysts, drivers and vectors for the purposeful or accidental introduction and spread of non-native/alien species into new areas, where some of them proliferate and spread (i.e., become invasive) (McNeely, 2001; Pyšek et al., 2004; Robbins, 2004; Richardson et al., 2011). It is now being acknowledged, though, that humans also mediate levels of invasibility of ecosystems by modifying disturbance regimes and altering landscapes and the environment (Kueffer, 2017). Other recent work has examined how invasive alien species affect humans and society, in particular by influencing livelihoods and human well-being (Shackleton et al., 2007; Pejchar and Mooney, 2009; Head and Atchison, 2015; Bacher et al., 2018). These effects on human well-being can influence the adoption or rejection of IAS within local cultures and livelihoods, which may modify people's perceptions, attitudes and beliefs and sometimes lead to conflicts of interest over the use and management of IAS (García-Llorente et al., 2008; Kull et al., 2011, 2018; van Wilgen et al., 2011; Estévez et al., 2015; Kueffer and Kull, 2017). To avoid, reduce, or solve these conflicts of interest, it is now understood that engagement with different stakeholders is critical when considering and implementing management options relating to biological invasions (Stokes et al., 2006; Bryce et al., 2011; Gaertner et al., 2016; Crowley et al., 2017; Novoa et al., 2018).

The aforementioned human and social dimensions research draws on multiple disciplines and approaches within the social sciences and humanities, just as there are diverse biological disciplines and 
approaches for studying IAS. The multiple phases and processes of biological invasions, which operate at different spatial and temporal scales, can require and influence the use of different sub-disciplinary approaches, theoretical perspectives and research paradigms. The "human and social dimensions" in the title of this paper refers to the suite of interactions that people have with IAS at different levels (individuals to societies); it also broadly encompasses different framings within social science and humanities sub-fields. The words "human" and "social" are often used interchangeably to relate to anything and everything to do with people (e.g., "The human dimensions of invasive species" (McNeely et al., 2001) and "The social dimensions of invasive alien plants" (Head, 2017)). The two words, however, sometimes have more specific meanings. Broadly speaking, "social" relates more closely to wider social, economic, political and cultural aspects. For instance, the theoretical, critical social sciences seek to understand societal processes underpinning the introduction and spread of invasive species and shaping their impacts, such as looking into political-economic power dynamics and "winners and losers". They also investigate how knowledge on invasions is produced and how broader conceptualisation and framing by different social groups shape our understanding and actions with respect to invasions (Kull, 2018). In turn, more applied social sciences might consider questions relating more closely to how to intervene and aid in the development of appropriate control actions and to manage conflicts of interest surrounding invasive species. In contrast, the "human" dimensions can be construed to focus more specifically on health impacts, or on psychological aspects such as cognition, learning, understanding, perceptions and behaviours of people.

This editorial paper explores developments in research on the human and social dimensions of biological invasions and how this research contributes to invasion science. We draw especially on papers from this special issue in the Journal of Environmental Management on the "Human and Social Dimensions in Invasion Science", which cover a broad range of social-ecological contexts and sub-disciplinary social science and humanities approaches and methods (Fig. 1 and Table 1); we also draw on the broader literature, especially on previous syntheses (e.g. McNeely, 2001; Rotherham and Lambert, 2011; Frawley and McCalman, 2014; Dobson et al., 2013; Head, 2017).

\section{The study of human and social dimensions within invasion science}

Studying the human and social dimensions of biological invasions has provided significant contributions to the discipline, but there is a need to identify emerging trends and to promote further research and integration. Below we discuss four areas that this special issue contributes to, and where we believe better insights on human and social dimensions are imperative for improving our understanding and management of invasive alien species in the future. These include: (1) people as a cause biological invasions; (2) how people conceptualise, understand and perceive invasions and management options; (3) how people are affected (positively and negatively) by biological invasions; and (4) and how people respond towards biological invasions (Fig. 2).

\subsection{People as a cause of invasions}

The most commonly used definition of IAS (sensu Richardson et al., 2000) specifies the fundamental role of human facilitation of species introductions across biogeographical barriers. Once introduced by humans these species, may establish, spread and become invasive. Besides introducing species, humans also alter and modify the recipient ecosystems, landscapes and the alien species themselves, thereby shaping invasion mechanisms and processes (McNeely, 2001; Hulme, 2006; Hui and Richardson, 2017; Kueffer, 2017). Understanding the role of humans in causing biological invasions is one of the better-researched areas concerning the human and social dimensions of invasion science (McNeely, 2001; Ruiz and Carlton, 2003). However, much more research is needed on factors such as people's deep motivations to introduce and spread invasive species and facilitate biological invasion processes and how these might change over space and time (Kowarik, 2003; Kueffer, 2017; Bennett and Van Sittert, this issue; Udo et al., this issue).

The terms "introduction pathway" and "invasion pathway" are often used to describe diverse processes associated with the introduction and dissemination of alien species and are commonly framed on the basis of ecological and sometimes social factors (Ruiz and Carlton, 2003; Hulme et al., 2008, 2009; Wilson et al., 2009; Essl et al., 2015). A number of studies on pathways discuss different reasons why and processes through which humans introduce alien species outside their native ranges. However, most of these studies do not address the deeper causal structures and mechanisms relating to human motivations, behaviours and patterns of spread. Although understanding the ecological processes that result in invasions is crucial, better understanding of the human drivers, social networks, and anthropogenic cause-and-effect relationships are also needed to improve policy and governance pertaining to biological invasions (Cole et al., this issue; Kueffer, 2017). This relates to answering questions about the motivations for introducing or spreading known invasive species, and how and why people make certain choices relating to the uptake of biosecurity measures to prevent spreading alien species. Better understanding temporal and spatial scales is also useful to improve knowledge and the social

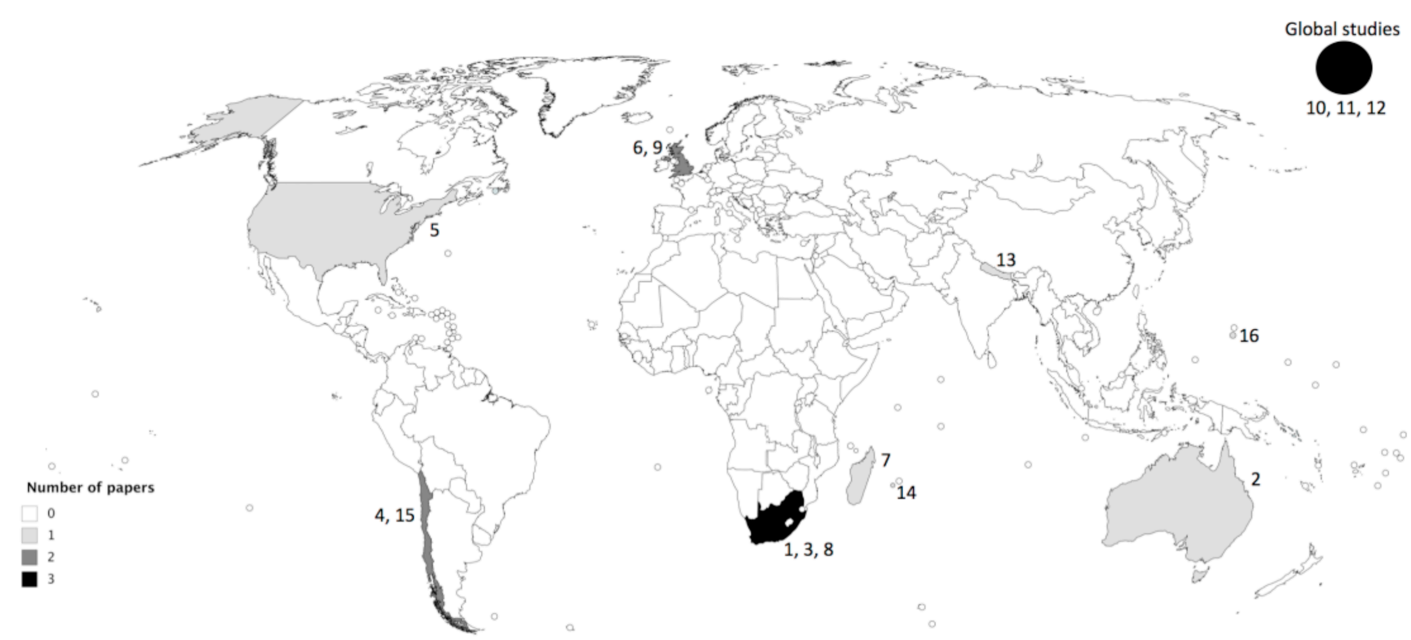

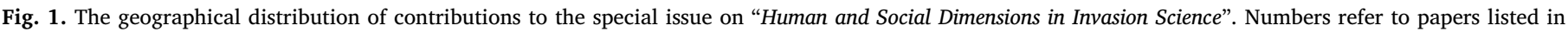
Table 1 which provides further details of each study. 


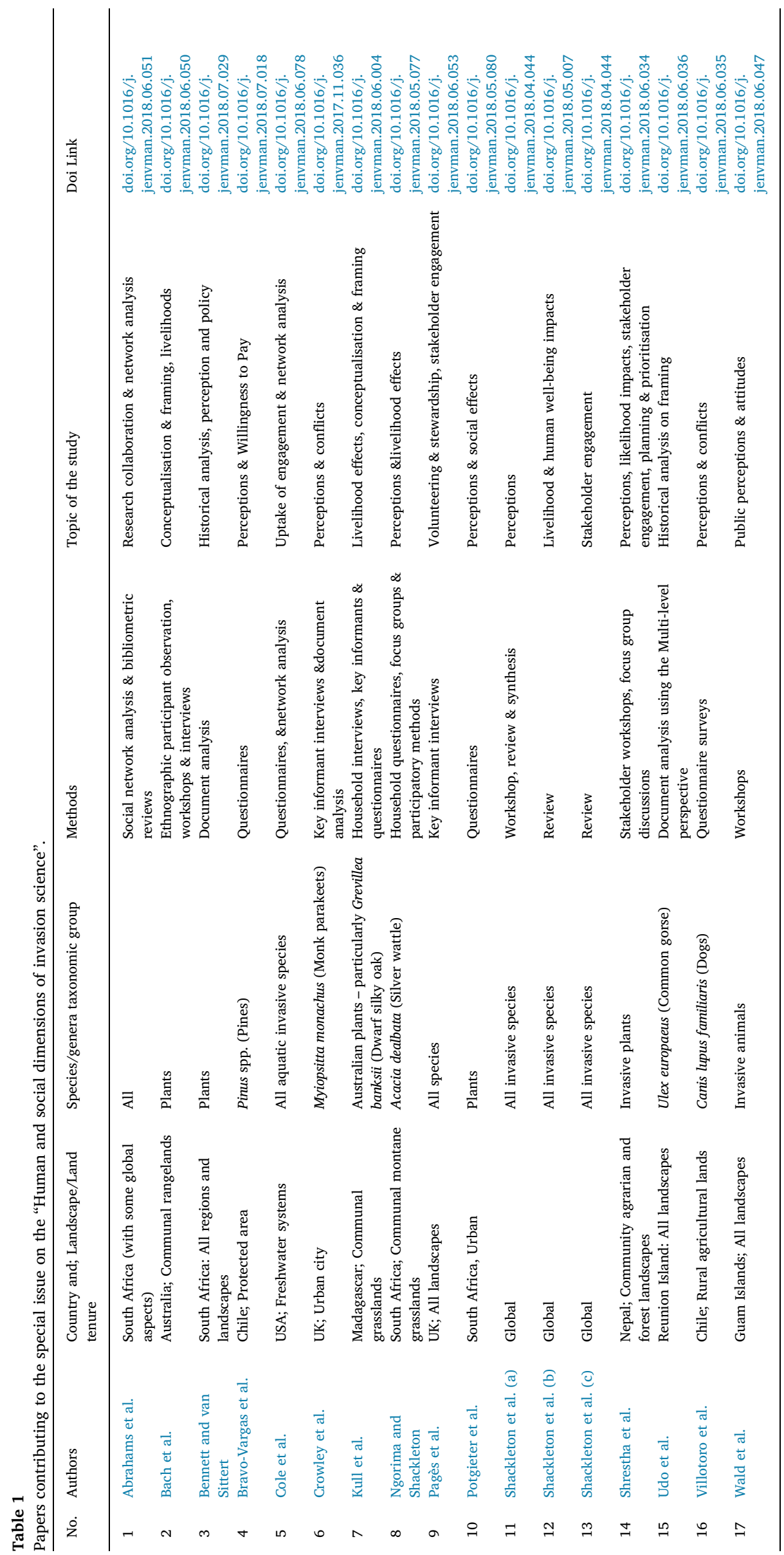




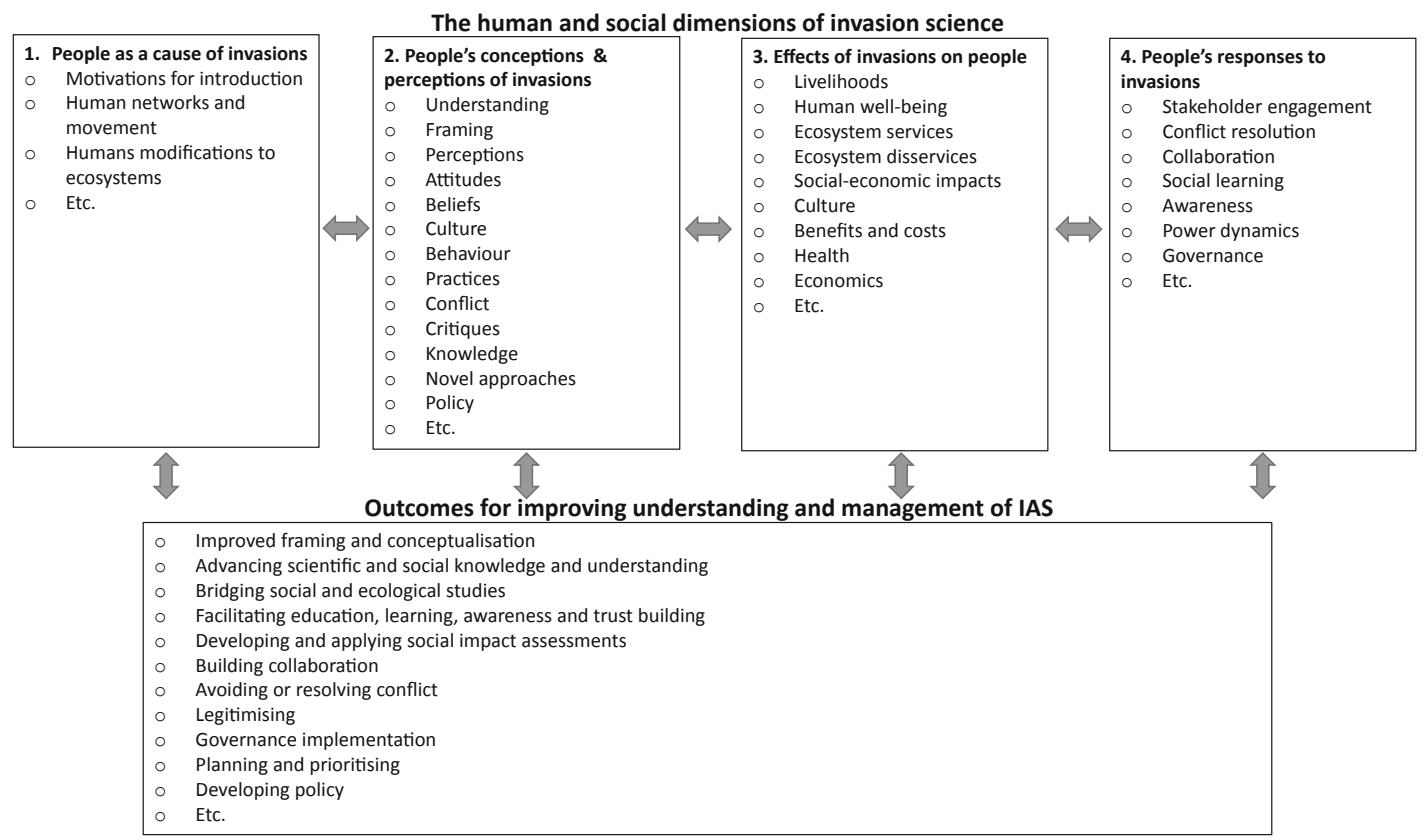

Fig. 2. Contributions of the human and social dimensions of invasion science and how they can help to improve understanding and management of biological invasions.

sciences have provided good insight regarding this. For example, focussing on the global history of Australian Acacia introductions, Carruthers et al. (2011) show that there have been different motivations or ethical considerations relating to introductions over time, due to changing cultural, economic and political contexts. Further work in the present special issue identifies changes over time in the introduction and facilitation of Ulex europaeus in Reunion Island (Udo et al., this issue), and the public attitudes towards the management of invasive plants in South Africa (Bennett and Van Sittert et al., this issue). At a smaller scale, Cole et al. (this issue) present an interesting study of how recreational boaters can cause biological invasions in waterbodies in the north-eastern USA through poor uptake of biosecurity measures or through purposeful introductions and direct disregard for generally accepted norms. Using interviews, they elicited information on the level of boater's uptake of biosecurity measures to prevent the accidental spread and to better understand the potential spread of invasive species from one water body to another using a coupled social and ecological network analyses. They show that there is a major interconnectedness between water bodies and that the increasing but not complete uptake of biosecurity measures means that the risk of people causing further spread of aquatic invasive species between different lakes is very high. Educational campaigns have changed boaters' actions over time, increasing their uptake of biosecurity measures, but more work is needed to improve compliance among the parties that do not follow biosecurity measures.

Another big question related to people causing invasions is how humans alter environments and species and how this alters invasion dynamics. This requires a more focussed input from the social sciences and humanities (McNeely, 2001; Hulme, 2006; Kueffer, 2017; Kull, 2018). This issue is still addressed primarily by ecologists, often using broad-scale models (e.g. Thuiller et al., 2006; Pyšek et al., 2010), considering mainly ecological factors (e.g. Hui et al., 2016), without giving enough attention to the societal processes implicated in invasions; elaboration on such issues is needed to improve understanding. The role of land use in facilitating or hindering invasions has been discussed before as the "human release hypothesis" (Zimmermann et al., 2014). This hypothesis highlights that the abundance of invasive alien species can be influenced by the level of human action or landscape maintenance. The authors discuss that intermediate levels of human activity likely facilitate invasions most, a point which needs to be better contextualised and researched in combination with important ecological drivers of invasions. Contributions to the special issue do not address this topic in depth and more research is needed in this area.

\subsection{People's conceptions and perceptions of invasions}

A second major contribution relates to how humans conceptualise, frame, understand and perceive invasions - i.e. how people think and feel about invasive alien species (Fig. 2). This can be approached in two ways, as we do in the two subsections below: 1) a more sociological approach relating to how groups of people broadly name, categorize and frame biological invasions; and 2) a more psychological approach focused on individuals' knowledge, attitudes and perceptions.

2.2.1. Conceptualisation and framing of biological invasions in invasion science and management

The ways in which biological invasions are framed, studied, and thought and talked about by different sectors of society has been an important focus of the social sciences and humanities (Head, 2017; Kull, 2018). Several contributions have been in the form of critiques leading to debates (e.g. see Brown and Sax (2004), Cassey et al. (2005), Warren (2007, 2009), Richardson et al. (2008), Preston (2009), Low (2012a, b) and Kull and Tassin (2012)). These debates have led to more objective framing and conceptualisation of the invasion phenomena and a more balanced and wider acknowledging and integration of different framings relating to invasions (Larson, 2005, 2007; Colautti and MacIsaac, 2004; Richardson and Ricciardi, 2013; Russel and Blackburn, 2017). This has also probably led more ecologically focused researchers to better consider the broader societal implications of their work.

Several papers in this special issue address the topic of conceptualisation and framing. For example, Bach et al. (this issue) argue that alternative framings such as "healthy country" (an Aboriginal view that relates to all living, non-living and spiritual parts of a system and their interactions (also see Burgess et al. (2005)) might be useful for guiding invasive species management on communal lands in Australia. The "healthy country" concept draws local knowledge and 
understanding into the conceptualisation of invasive species management options. Bach et al. (this issue) stress the need to move away from traditional weed lists (that simply list all invasive species) to improve management uptake. In particular, this concept acknowledges the dynamic nature of landscapes and includes priorities based on local values and a post-colonial stance (Head and Atchison, 2015). This could lead to the uptake of novel control approaches and improve prioritisation and management implementation. Kull et al. (this issue) study the transition of grasslands and degraded areas to "neo-Australian forests" in Madagascar. They discuss the importance of acknowledging diverse framings from different actors such as "beneficial landscape greening" (foresters and certain NGOs), "rampant biological invasion" (invasion biologists), and "novel ecosystems" (some ecologists). They argue that local non-academic perspectives are often excluded and propose that researchers and policy makers need to better incorporate a more bottom-up and local understanding. Narratives or framings of invasive alien species are often related to a dominant set of actors in a particular context, and usually reflect particular social constructs like political institutions and laws implemented by powerful actors (Dobson et al., 2013; Head and Atchison, 2015; Bennett and van Sittert, this issue; Udo et al., this issue). Several contributions stress that the conceptualisation and framing of invasive alien species is often dynamic in time - e.g. $U$. europaeus on La Réunion went "from useful to invasive" over the past century (Udo et al. this issue). Similarly, Bennett and van Sittert (this issue) show that framing and conceptualisation differ over space and time in South Africa. They show how historical responses to invasive species, in some cases around a century ago, in one area of South Africa (the broad Cape region) shaped present policy and practice for the whole country. Future work on invasions clearly needs to acknowledge the existence of different framings to reduce conflicts and ensure balanced solutions (Woodford et al., 2016). This could also help with engaging actors (see below), potentially providing shared understanding and solutions to maximize benefits and reduce costs for the broader society (Kull et al., 2011; Head et al., 2015; Novoa et al., 2015, 2016).

\subsubsection{Understanding people's knowledge, perceptions and behaviours}

People's value systems and knowledge affect their understanding, conceptualisation and behaviours. Perceptions of invasive alien species are often diverse, frequently leading to conflicts of interest relating to the introduction and management of invasive species when opposing views arise (Crowley et al., 2017; Shackleton et al., this issue a). In this special issue, the broad-scale factors that influence people's perceptions relating to invasive alien species are covered in a conceptual framework that highlights six core and a number of other underlying factors. These include: the individual(s) concerned; the effects of the invasive species; the species itself (and its traits); the social-cultural context; the landscape context; and the institutional, governance and policy contexts (Shackleton et al., this issue a).

Several contributions in the special issue also describe case studies in different contexts that elucidate some of the concepts from the framework proposed by Shackleton et al. (this issue a). For example, working in urban ecosystems and focussing on a number of invasive alien plants, Potgieter et al. (this issue) show how people's knowledge of the effects of invasive species (ecosystem services and disservices) can influence perceptions. They also discuss how such knowledge is also strongly influenced by demographic profiles defined by education level and wealth status. For example, people with higher education levels and more exposure to environmental hazards perceive invasive species more negatively and are more likely to support management, but also have a clearer understanding of the positive aspects of some species. Also in the urban context, Crowley et al. (this issue) show how personal value systems and experiences influence perceptions and behaviours relating to charismatic invasive species and how this can lead to conflicts regarding their management. They also detail how societal interactions and governance contexts among different actors can influence and reinforce particular perceptions. Villatoro et al. (this issue) discuss similar issues relating to different values, perceptions and the resulting conflict of interests regarding the management of feral dogs in rural Chile. In particular, they highlight that people were less in favour of lethal forms of management and supported other options such as sterilisation. People also perceived impacts on wildlife as less of an issue than impacts on humans or livestock. In a protected area of Chile, Bravo-Vargas et al. (this issue) highlight contrasting social values and perceptions relating to the control of invasive pine trees - particularly contrasting perceptions relating to summer vs. winter visitors and landscapes. Wald et al. (this issue) showed that having positive interactions with managers changed perceptions of invasive species and their management and increased support for control and trust from different authorities in Guam.

Perceptions clearly change over time, and historical analyses are useful for identifying milestones and triggers for such changes in perception (Bennett and van Sittert, this issue; Udo et al., this issue), and further work is needed in this area. Different conceptualisation, values, perceptions, and behaviours can lead to conflicts of interest which can hinder management (Novoa et al., 2018; Crowley et al., this issue; Shackleton et al., this issue). A key to moving forward with managing invasions is understanding how values and perceptions translate into practices and behaviours, and the barriers that often hinder such translation. We also need further work to develop methods for assessing the roles of specific contexts and the complex factors that influence people's perceptions.

\subsection{Effects of invasions on people}

A large body of work seeks to improve our understanding of how invasive species affect humans and society. This topic of research addresses the quantification of positive and negative effects of invasive alien species on humans and society, particularly using frameworks like ecosystem services and disservices, human well-being and local livelihoods (Shackleton et al., 2007; Pejchar and Mooney, 2009; Kull et al., 2011; Vaz et al., 2017b; Bacher et al., 2018). Several studies in the special issue address this topic. Shackleton et al. (this issue b), through a global review, provide insights on how invasive alien species affect livelihoods and human well-being by quantifying the various benefits and costs of invasive species and assessing the role of social-ecological contexts in shaping the effects of invasive alien species in different settings.

In a more local context (the city of Cape Town), Potgieter et al. (this issue) show that invasive alien plants have both positive and negative effects for city dwellers. Some of these key positive effects include cultural services relating to shade, recreation and aesthetics, and provisioning services such as fuelwood. Several negative effects or disservices were also highlighted, the primary ones being loss of water supply and native biodiversity and issues pertaining to how invasive alien species can reduce local people's safety and security through hazards like changing fire regimes and increasing crime. In a rural communal grassland setting in South Africa, Ngorima and Shackleton (this issue) show how the invasive tree Acacia dealbata provides benefits for local livelihoods (in particular fuelwood which can also generate income) and negative impacts (impacting on human security, water supply and grazing potential). They detail the niche filled by this tree in the context of a relatively treeless high altitude grrassland biome is crucial for the supply of some services for locals. However, ways need to be found to maintain benefits for individual livelihoods while reducing the costs for the broader society. Kull et al. (this issue) describe the importance of Australian trees (especially Grevillea banksii) for charcoal production, a key livelihood activity in the rural lands of eastern Madagascar (Kull et al., this issue). In rural Nepal, numerous invasive alien plant species also generate substantial negative impacts for locals such as loss of grazing, poisoning of livestock, and reductions in crop production and in the ability to harvest forest products. 
However, a few species provided limited benefits in the form of fodder, biomass for composting, medicinal products and soil stabilisation (Shrestha et al., this issue). Local populations in Guam considered the social effects of the invasive brown tree snake (Boiga irregularis) to be minimal, but were highly concerned about the negative impacts of the invasive coconut rhinoceros beetle (Oryctes rhinoceros) which kills coconut trees, an important source of income and food for local livelihoods and is also a tree with high cultural value on the island (Wald et al., this issue). In Chile, people were more concerned about the negative impacts of feral dogs on human health and safety and livestock (economic issues) than impacts on native biodiversity (Villatoro et al., this issue), showing that sometimes the social effects of invasive species are of more concern than their biological ones.

This research particularly reinforces the view that socioeconomic effects of invasive species are often very context specific. For instance, Australian acacias are generally perceived more positively and have fewer impacts in Madagascar than in South Africa - which is likely based on differences in land-use intensity and features of land tenure (Kull et al., 2011; Kull et al., 2018; Ngorima and Shackleton et al., this issue; Shackleton et al., this issue b). Similarly, Lantana camara is widely perceived to have major negative impacts and very few benefits in East Africa, whereas in some Indian communities the species provides important benefits as it has replaced and substituted overused native bamboos for furniture making and ensured continuity of an important livelihood practice for some communities (Kannan et al., 2014; Shackleton et al., 2017). The effects of invasive species on humans and society can also change over time (Shackleton et al., 2007; Shackleton et al., this issue b; Udo et al., this issue). However, little research has been done on changes in the socioeconomic effects of invasive species over time and more work is needed in this area. Much of the work that has been done has focused on the developing world and insights from the "north" are needed. Most attention has been given to understanding the effects of invasive alien species on material and tangible benefits and costs (Shackleton et al., this issue b). However, there are also more abstract benefits and costs relating to human values and local culture that need further elucidation (Estévez et al., 2015; Bach et al., this issue; Crowley et al., this issue; Potgieter et al., this issue). One aspect that is lacking is an objective basis for comparing trade-offs among different actors and for assessing how different power dynamics between different stakeholders relate to and influence social benefits, costs, and decision-making. Contributions to this special issue have been useful for understanding the different socioeconomic effects of invasive alien species and showing how these can help with planning and prioritising control efforts, and avoiding or mitigating conflicts of interest (Shackleton et al., this issue b; Shrestha et al., this issue) (Fig. 2).

\subsection{People's responses to invasions}

The fourth focus area derived from this special issue relates to people responding to invasions via management planning and implementation which commonly requires stakeholder engagement (Fig. 2). It links to questions of what to do, who decides, how to do it, and who will do it? Social engagement is rapidly gaining traction as it has been realised that in many cases different stakeholders and actors are involved in different facets of the invasion and management processes, and therefore management planning and implementation demand engagement with all stakeholders to ensure effective adaptive governance (Folke et al., 2005; Bryce et al., 2011; Novoa et al., 2018; Reed et al. 2017). Adaptive governance draws on multiple knowledge systems and actors and processes to provide shared development and understanding of sustainable policies and management implementation (Folke et al., 2005). Social factors can act as both a barrier to and an enabler of effective governance and management responces; this generates substantial complexity and complicates the task of engagement, but also makes it more necessary (van Wilgen and Richardson, 2012;
Shackleton et al., 2016; Head et al., 2017).

A number of different approaches for engagement can be used depending on the aim of the the reponce (Shackleton et al., this issue c). For example, Shrestha et al. (this issue) used participatory community meetings to assess local knowledge and aid with prioritisation planning. Many studies used questionnaires in a top-down, purely research-orientated manner to assess public practices and perceptions (e.g. Cole et al., this issue; Villatoro et al., this issue; Shackleton et al., this issue c; Kull et al., this issue). Others used in-depth interviews to achieve a deeper understanding of particular phenomena or problems, but again focus more on research output (Bach et al., this issue; Pagés et al., this issue; Wald et al., this issue). Other options include participatory rural appraisal and mapping, scenario planning, collaborative implementation and citizen science and stewardship to aid with development and implementation of responces (e.g. see Bryce et al., 2011; Luizza et al., 2016; Pagés et al., this issue).

Stakeholder engagement is often conducted as an input to planning and prioritisation of management. For example, Shrestha et al. (this issue) used participatory community meetings to rank invasive alien species in terms of their negative effects and management priorities. Other specialised methodologies like multi-criteria decision making have also been developed to engage stakeholders in decisions, for example, to assign priority to certain invasive alien species and landscape units for management (e.g. see Lui et al., 2010; Forsyth et al., 2012).

Many invasive species generate conflicts of interest, and engagement is crucial for avoiding, reducing or resolving such conflicts (Crowley et al., 2017; Zengeya et al., 2017; Novoa et al., 2018; Crowley et al., this issue; Villatoro et al., this issue). Approaches used to deal with conflicts include building social learning and trust between parties and promoting effective communication (Novoa et al., 2016, 2018; Crowley et al., this issue; Wald et al., this issue). Crowley et al. (this issue) stress the need for collaborative planning, transparency and inclusivity to ensure effective management and to prevent conflict; they emphasize that disregarding public opinions and values is a fundamental mistake when designing management strategies for invasive species. Novoa et al. (2016) showed that conflicts can be reduced by engaging different actors in discussions regarding the impacts of invasive cacti and their management options, and that this can lead to better understanding and improved consensus between opposing actors, thereby aiding in the development of management interventions that are supported by all parties.

Engagement aiming to awareness raising and social learning is also important when devising strategies to manage invasions (Reed et al., 2010; Cole et al., this issue; Pagés et al., this issue; Shackleton et al., this issue c). For example, Cole et al. (this issue) highlight that awareness rising and education campaigns have improved local recreational boaters' biosecurity actions with regards to preventing the spread of aquatic invasive species. Bravo-Vargas et al. (this issue) show that even very limited awareness raising regarding pine invasions in a Chilean national park can increase support and willingness to pay for management.

Developing and aiding collaboration, co-management and adaptive governance is also crucial to ensure successful responses to invasions (Jentoft et al., 1998; Armitage et al., 2009; Bryce et al., 2011; Shackleton et al., this issue c). Co-management is important to ensure that multiple actors take ownership and aid with control of invasive alien species. This approach is particularly important in the context of invasions because there are often many different stakeholders, e.g. those involved in introducing and disseminating the alien species, those who may profit from the presence of the species, and those affected by invasions in different parts of the landscape. Improved collaboration and co-implementation of control can also aid in reducing the burden of management of invasive species by the state and lead to shared responsibility.

Another component relating to engagement is citizen science and volunteering initiatives to monitor and control invasive species which 
links to both co-management and social learning; this is a growing area of interest in invasion science (Marchante et al., 2017; Ricciardi et al., 2017; Pagés et al., this issue). Citizen science reporting and monitoring has been highly useful in a number of regions to provide better understanding of invasive species distributions (Marchante et al., 2017; Shackleton et al., this issue c). Similarly, there are many programs in which people volunteer their services to control invasive alien species (Pagés et al., this issue). Although citizen science and volunteering can benefit multiple parties, Pagés et al. (this issue) discuss the intricate nature of volunteering programmes and the need to carefully address different people's motivations and expectations to ensure alignment between the agendas of different parties. This is needed to ensure satisfaction of volunteers, provide empowerment with regards to control, and to ensure the long-term sustainability of such projects.

Finally, a review by Shackleton et al. (this issue c) revealed that although research that includes social engagement is on the rise, most of this work is done in a top-down manner, with the aim of understanding people's perceptions. They argue that future work should be more integrative and should include more co-design and co-implementation and should seek to increase social learning. Different actors' wants, needs and agendas need to be accounted for (Pagés et al., this issue). There is also need to incorporate more bottom-up rather than top-down engagement and better understanding of power dynamics (Shackleton et al., this issue c).

\section{Conclusions}

We have illustrated some of the crucial research contributions relating to the human and social dimensions of invasion science and their role in improving understanding and management of biological invasions.

The contributions to the special issue remind us that biological invasions are as inherently social as they are biological and are perfect example of socio-natural hybrid interactions and systems (Robbins, 2001; Head, 2017). Further inputs from the social sciences and humanities are urgently needed to improve our understanding of the context and complexity of invasions and their management. This often relates to trade-offs and conflicts, especially those caused by the diverse socialeconomic benefits and costs of invasions and by the different human values, perceptions and behaviours. It is also important to acknowledge and understand the different ways of framing and understanding biological invasions. Research and management is often conducted in a fairly top-down, non-collaborative manner. Better collaborations and more bottom-up engagement should be sought to ensure better uptake of policy and management practices. This will help to address fundamental challenges especially relating to issues like conflicts of interest, aiding with prioritisation and cooperative management implementation. More research should be facilitated through improved socialecological collaboration and inter- or transdisciplinarity (Kueffer, 2010, 2013; Turner et al., 2016). The need for inter and transdisciplinary understanding is slowly being recognised, but more fundamental biological research in the field still dominates, and further cross collabration is needed (Vaz et al., 2017a). Working in a more interdisciplinary manner, and more closely with local communities, practitioners and policy makers, will improve the relevance of research in invasion science. This includes putting more emphasis on training young social scientists and humanities scholars to become leaders or champions in the field and setting up better global networks for invasion science with better representation from the social sciences and humanities (Packer et al., 2017; Abrahams et al., this issue).

\section{Acknowledgments}

We thank all the contributors to the special issue and the editorial staff of Journal of Environmental Management for helping to make it a smooth process. In particular, we thank the Editor-in-Chief, Berrin
Tensil, who facilitated the issue and provided much support. Many funding sources contributed to allow the special issue to happen. We acknowledge funding from the DST-NRF Centre of Excellence for Invasion Biology (where the idea for the special issue was born), the Social Sciences and Humanities Research Council of Canada (SSHRC), the Swiss government through the Swiss Government Excellence Scholarship, Stellenbosch University (through "Consolidoc funding" of the office of the Vice Rector: Research, Innovation and Postgraduate Studies to RTS), and the National Research Foundation, South Africa (grant 85417 to DMR). AN acknowledges funding from the Project No. 14-36079G Centre of Excellence PLADIAS (Czech Science Foundation) and the long-term research development project RVO 67985939 (The Czech Academy of Sciences). RTS also thanks Charlie Shackleton and the South African Research Chairs Initiative of the Department of Science and Technology and the National Research Foundation of South Africa for helping to fund a workshop in Lisbon, Portugal, in September 2017.

\section{References}

Abrahams, B., Sitas, N., Esler, K.J., in this issue. Exploring the dynamics of research collaborations by mapping social networks in invasion science. J. Environ. Manag.. https://doi.org/10.1016/j.jenvman.2018.06.051.

Armitage, D.R., Plummer, R., Berkes, F., Arthur, R.I., Charles, A.T., Davidson-Hunt, I.J., Diduck, A.P., Doubleday, N.C., Johnson, D.S., Marschke, M., McConney, P., 2009. Adaptive co-management for social-ecological complexity. Front. Ecol. Environ. 7, 95-102.

Bach, T.M., Kull, C.A., Rangan, P., in this issue. Killing lists to healthy country: Aboriginal approaches to weed control in Kimberly, Western Australia. J. Environ. Manag. https://doi.org/10.1016/j.jenvman.2018.06.050.

Bacher, S., Blackburn, T.M., Essl, F., Genovesi, P., Heikkilä, J., Jeschke, J.M., Jones, G., Keller, R., Kenis, M., Kueffer, C., Martinou, A.F., Nentwig, W., Pergl, J., Pyšek, P., Rabitsch, W., Richardson, D.M., Roy, H.E., Saul, W., Scalera, R., Vilà, M., Wilson, J.R.U., Kumschick, S., 2018. Socio-economic impact classification of alien taxa (SEICAT). Meth. Ecol. Evol. 9, 159-168.

Backstrom, A.C., Gerrard, G.E., Hobbs, R.J., Bekessy, S.A., 2018. Grappling with the social dimensions of novel ecosystems. Front. Ecol. Environ. 16, 109-117.

Bennett, B.M., van Sittert, L., in this issue. Perceptions of invasive alien plants in South Africa: historicising the national framework. J. Environ. Manag.. https://doi.org/10. 1016/j.jenvman.2018.07.029.

Bennett, N.J., Roth, R., Klain, S.C., Chan, K., Christie, P., Clark, D.A., Cullman, G., Curran, D., Durbin, T.J., Epstein, G., Greenberg, A., Nelson, M.P., Sandlos, J., Stedman, R., Teel, T.L., Thomas, R., Veríssimo, D., Wyborn, C., 2017a. Conservation social science: understanding and integrating human dimensions to improve conservation. Biol. Conserv. 205, 93-108.

Bennett, N.J., Roth, R., Klain, S.C., Chan, K., Clark, D.A., Cullman, G., Epstein, G., Nelson, M.P., Stedman, R., Teel, T.L., Thomas, R.E.W., Wyborn, C., Currn, D., Greenberg, A., Sandlos, J., Veríssimo, D., 2017b. Mainstreaming the social sciences in conservation. Conserv. Biol. 31, 56-66.

Berkes, F., Folke, C., Colding, J., 2000. Linking Social and Ecological Systems: Management Practices and Social Mechanisms for Building Resilience. Cambridge University Press.

Bravo-Vargas, Garcia, R.A., Pizarro, C. and Pauchard, A., in this issue. Do people care about pine invasions? Visitor perceptions and willingness to pay for pine control in a protected area. J. Environ. Manag.. https://doi.org/10.1016/j.jenvman.2018.07.018.

Brown, J.H., Sax, D.F., 2004. An essay on some topics concerning invasive species. Austral Ecol. 29, 530-536.

Bryce, R., Oliver, M.K., Davies, L., Gry, H., Urquhart, J., Lambin, X., 2011. Turning back the tide of American mink invasion at an unprecedented scale trough community participation and adaptive management. Biol. Conserv. 144, 575-583.

Burgess, C.P., Johnston, F.H., Bowman, D.M., Whitehead, P.J., 2005. Healthy country: healthy people? Exploring the health benefits of Indigenous natural resource management. Australian and New Zealand J. Publ. Health 29, 117-122.

Carruthers, J., Robin, L., Hattingh, J.P., Kull, C.A., Rangan, H., van Wilgen, B.W., 2011. A native at home and abroad: the history, politics, ethics and aesthetics of acacias. Divers. Distrib. 17, 810-821.

Cassey, P., Blackburn, T.M., Duncan, R.P., Chown, S.L., 2005. Concerning invasive species: reply to Brown and Sax. Austral Ecol. 30, 475-480.

Christie, P., Bennett, N.J., Gray, N.J., Wilhelm, T.A., Lewis, N.A., Parks, J., Ban, N.C., Gruby, R.L., Gordon, L., Day, J., Taei, S., 2017. Why people matter in ocean governance: incorporating human dimensions into large-scale marine protected areas Mar. Pol. 84, 273-284.

Colautti, R.I., MacIsaac, H.J., 2004. A neutral terminology to define 'invasive' species. Divers. Distrib. 10, 135-141.

Cole, E., Keller, R.P., Garbach, K., in this issue. Risk of invasive species spread by recreational boaters remains high despite widespread adoption of conservation behaviours. J. Environ. Manag.. https://doi.org/10.1016/j.jenvman.2018.06.078.

Crosby, A., 1986. Ecological Imperialism: the Biological Expansion of Europe. Cambridge University Press, Cambridge, pp. 900-1900.

Crowley, S.L., Hinchliffe, S., McDonald, R.A., in this issue. The parakeet protectors: 
understanding opposition to introduced species management. J. Environ. Manag.. https://doi.org/10.1016/j.jenvman.2017.11.036.

Crowley, S.L., Hinchliffe, S., McDonald, R.A., 2017. Conflict in invasive species management. Front. Ecol. Environ. 15, 133-141.

Decker, D.J., Riley, S.J., Siemer, W.F., 2012. Human Dimensions of Wildlife Management. Johns Hopkins University Press, Baltimore.

Dobson, A., Barker, K., Taylor, S.L., 2013. Biosecurity: the Socio-politics of Invasive Species and Infectious Diseases. Routledge-Earthscan, London.

Elton, C.S., 1958. The Ecology of Invasions by Animals and Plants. Methuen, London.

Essl, F., Bacher, S., Blackburn, T.M., Booy, O., Brundu, G., Brunel, S., Cardoso, A.C., Eschen, R., Gallardo, B., Galill, B., García-Berthou, E., Genovesi, P., Groom, Q., Harrower, C., Hulme, P.E., Katsanevakis, S., Kenis, M., Kühn, I., Kumschick, S., Martinou, K., Nentwig, W., O'Flynn, C., Pagad, S., Pergl, J., Pyšek, P., Rabitsch, W., Richardson, D.M., Roques, A., Roy, H.E., Scalera, R., Schindler, S., Seebens, H., Vanderhoeven, S., Vilà, M., Wilson, J.R.U., Zenetos, A., Jeschke, J.M., 2015. Crossing frontiers in tackling pathways of biological invasions. Bioscience 65, 769-782.

Estévez, R.A., Anderson, C.B., Pizarro, J.C., Burgman, M.A., 2015. Clarifying values, risk perceptions and attitudes to resolve or avoid social conflicts in invasive species management. Conserv. Biol. 29, 19-30.

Farwley, J., McCalman, I., 2014. Rethinking Invasion Ecologies from the Environmental Humanities. Routledge, New York.

Folke, C., Hahn, T., Olsson, P., Norberg, J., 2005. Adaptive governance of social-ecological systems. Annu. Rev. Environ. Resour. 30, 441-473.

Forsyth, G.G., Le Maitre, D.C., O'Farrell, P.J., van Wilgen, B.W., 2012. The prioritisation of invasive alien plant control projects using a multi-criteria decision model informed by stakeholder input and spatial data. J. Environ. Manag. 103, 51-57.

Gaertner, M., Larson, B.M.H., Irlich, U.M., Holmes, P.M., Stafford, L., van Wilgen, B.W., Richardson, D.M., 2016. Managing invasive species in cities: a framework from Cape Town, South Africa. Landsc. Urban Plann. 151, 1-9.

García-Llorente, M., Martín-López, B., González, J.A., Alcorlo, P., Montes, C., 2008. Social perceptions of the impacts and benefits of invasive alien species: implications for management. Biol. Conserv. 141, 2969-2983.

Harlan, J.R., de Wet, J.M.J., 1965. Some thoughts about weeds. Econ. Bot. 19, 16-24.

Head, L., 2017. The social dimensions of invasive plants. Nat. Plants 3, 17075.

Head, L., Atchison, J., 2015. Entangled invasive lives: indigenous invasive plant management in northern Australia. Geografiska Annaler: series B. Hum. Geogr. 97, 169-182.

Head, L., Larson, B.M.H., Hobbs, R.J., Atchison, J., Gill, N., Kull, C.A., Rangan, H., 2015. Living with invasive plants in the Anthropocene: the importance of understanding practice and experience. Conserv. Soc. 13, 311-318.

Hui, C., Richardson, D.M., 2017. Invasion Dynamics. Oxford University Press, Oxford.

Hui, C., Richardson, D.M., Landi, P., Minoarivelo, H.O., Garnas, J., Roy, H.E., 2016. Defining invasiveness and invasibility in ecological networks. Biol. Invasions 18 , 971-983.

Hulme, P.E., 2006. Beyond control: wider implications for the management of biological invasions. J. Appl. Ecol. 43, 835-847.

Hulme, P.E., 2009. Trade, transport and trouble: managing invasive species pathways in an era of globalization. J. Appl. Ecol. 46, 10-18.

Hulme, P.E., Bacher, S., Kenis, M., Klotz, S., Kühn, I., Minchin, D., Nentwig, W., Olenin, S., Panov, V., Pergl, J., Pyšek, P., 2008. Grasping at the routes of biological invasions: a framework for integrating pathways into policy. J. Appl. Ecol. 45, 403-414.

Jentoft, S., McCay, B.J., Wilson, D.C., 1998. Social theory and fisheries co-management. Mar. Pol. 22, 423-436.

Kannan, R., Shackleton, C.M., Shaanker, R.U., 2014. Invasive alien species as drivers in socio-ecological systems: local adaptions towards use of Lantana in Southern India Environ. Dev. Sustain. 16, 649-669.

Kowarik, I., 2003. Human agency in biological invasions: secondary releases foster naturalisation and population expansion of alien plant species. Biol. Invasions 5 , 293-312.

Kueffer, C., 2010. Transdisciplinary research is needed to predict plant invasions in an era of global change. Trends Ecol. Evol. 25, 619-620.

Kueffer, C., 2013. Integrating natural and social sciences for understanding and managing plant invasions. In: Larrue, S. (Ed.), Biodiversity and Society in the Pacific Islands. Presses Universitaires de Provence, Marseille, \& ANU ePress, Canberra, pp. 71-95.

Kueffer, C., 2017. Plant invasions in the anthropocene. Science 358, 724-725.

Kueffer, C., Kull, C., 2017. Non-native species and the aesthetics of nature. In: Hulme, P., Vilà, M., Ruiz, G. (Eds.), Impact of Biological Invasions on Ecosystem Services. Springer, Berlin, pp. 311-324.

Kull, C.A., 2018. Critical invasion science: weeds, pests, and aliens. In: Biermann, L.R.C., Lane, S.N. (Eds.), The Palgrave Handbook of Critical Physical Geography. Palgrave Macmillan, Switzerland, pp. 249-272.

Kull, C.A., Tassin, J., 2012. Australian acacias. Sometimes useful (sometimes) weedy. Biol. Invasions 14, 2229-2233.

Kull, C.A., Harimanana, S.L., Radaniela Andrianoro, A., Rajoelison, L.G., in this issue. Divergent perceptions of the 'neo-Australian' forests of lowland eastern Madagascar: Invasions, transitions, and livelihoods. J. Environ. Manag.. https://doi.org/10.1016/ j.jenvman.2018.06.004.

Kull, C.A., Shackleton, C.M., Cunningham, P.S., Ducatillon, C., Dufour Dror, J.M., Esler, K.J., Friday, J.B., Gouveia, A.C., Griffin, A.R., Marchante, E.M., Midgley, S.J., Pauchard, A., Rangan, H., Richardson, D.M., Rinaudo, T., Tassin, J., Urgenson, L.S., von Maltitz, G.P., Zenni, R.D., Zylstra, M.J., 2011. Adoption, use and perception of Australian acacias around the world. Divers. Distrib. 175, 822-836.

Kull, C.A., Kueffer, C., Richardson, D.M., Vaz, A.S., Vicente, J., Honrado, J.P., 2018. Using the 'regime shift' concept in addressing social-ecological change. Geogr. Res. 56, 26-41. https://doi.org/10.1111/1745-5871.12267.

Larson, B.M.H., 2005. The war of the roses: demilitarizing invasion biology. Front. Ecol.
Environ. 3, 495-500

Larson, B.M., 2007. An alien approach to invasive species: objectivity and society in invasion biology. Biol. Invasions 9, 947-956.

Le Maitre, D.C., Richardson, D.M., Chapman, R.A., 2004. Alien plant invasions in South Africa: driving forces and the human dimension. South Afr. J. Sci. 100, 103-112.

Low, T., 2012a. Australian acacias: weeds or useful trees? Biol. Invasions 14, 2217-2227.

Low, T., 2012b. In denial about dangerous aid. Biol. Invasions 14, 2235-2236.

Lui, S., Proctor, W., Cook, D., 2010. Using an integrated fuzzy set and deliberative multicriteria evaluation approach to facilitate decision-making in invasive species management. Ecol. Econ. 69, 2374-2382.

Luizza, M.W.M., Walkie, T., Evangelisat, P.H., Jarnevisch, C.S., 2016. Integrating local pastoral knowledge, participatory mapping, and species distribution modeling for risk assessment of invasive rubber vine (Cryptostegia grandiflora) in Ethiopia's Afar region. Ecol. Soc. 21, 22.

Marchante, H., Morais, M.C., Gamela, A., Marchante, E., 2017. Using a WebMapping platform to engage volunteers to collect data on invasive plants distribution. T. GIS 21, 238-252.

McNeely, J.A., 2001. The Great Reshuffling: Human Dimensions of Invasive Alien Species. IUCN, Gland.

Mitman, G., 2004. When pollen became poison: a cultural geography of ragweed in America. In: Daston, L., Vidal, F. (Eds.), Moral Authority of Nature. University of Chicago Press, Chicago, pp. 438-465.

Ngorima, A., Shackleton, C.M., in this issue. Livelihood benefits and costs of an invasive alien tree (Acacia dealbata) to rural communities in the Eastern cape, South Africa. J. Environ. Manag.. https://doi.org/10.1016/j.jenvman.2018.05.077.

Novoa, A., Kaplan, H., Kumschick, S., Wilson, J.R.U., Richardson, D.M., 2015. Soft touch or heavy hand? Legislative approaches for preventing invasions: insights from cacti in South Africa. Invasive Plant Sci. Manag. 8, 307-316.

Novoa, A., Kaplan, H., Wilson, J.R.U., Richardson, D.M., 2016. Resolving a prickly situation: involving stakeholders in invasive cactus management in South Africa. Environ. Manag. 57, 998-1008.

Novoa, A., Shackleton, R.T., Canavan, S., Cybéle, C., Davies, S., Dehnen-Schmutz, K., Fried, J., Gaertner, M., Geerts, S., Griffiths, C., Kaplan, H., Kumschick, S., Le Maitre, D.C., Measey, G.J., Nunes, A.L., Richardson, D.M., Robinson, T.B., Touza, J., Wilson, J.R.U., 2018. A framework for engaging stakeholders on the management of alien species. J. Environ. Manag. 205, 286-297.

Ostrom, E., 2009. A general framework for analyzing sustainability of social-ecological systems. Science 325, 419-422.

Packer, J.G., Meyerson, L.A., Richardson, D.M., Brundu, G., Allen, W.J., Bhattarai, G.P., Brix, H., Canavan, S., Castiglione, S., Cicatelli, A., Čuda, J., 2017. Global networks for invasion science: benefits, challenges and guidelines. Biol. Invasions 19, 1081-1096.

Pagès, M., van der Wal, R., Lambin, X., Fischer, A., in this issue. Involving volunteers in rationalised nature conservation: challenges and opportunities in the case of nonnative species management in Great Britain. J. Environ. Manag.. https://doi.org/10. 1016/j.jenvman.2018.06.053.

Pejchar, L., Mooney, H.A., 2009. Invasive species, ecosystem services and human wellbeing. Trends Ecol. Evol. 24, 497-504.

Peretti, J.H., 1998. Nativism and nature: rethinking biological invasion. Environ. Val. 7, 183-192.

Potgieter, L., Gaertner, M., O'Farrell, P.J., Richardson, D.M. This issue. Perceptions of impact: invasive alone plants in the urban environment. J. Environ. Manag.. https:// doi.org/10.1016/j.jenvman.2018.05.080.

Preston, C.D., 2009. The terms 'native' and 'alien'-a biogeographical perspective. Prog. Hum. Geogr. 33, 702-711.

Pyšek, P., Richardson, D.M., Rejmánek, M., Webster, G.L., Williamson, M., Kirschner, J., 2004. Alien plants in checklists and floras: towards better communication between taxonomists and ecologists. Taxon 53, 131-143.

Pyšek, P., Jarošík, V., Hulme, P.E., Kühn, I., Wild, J., Arianoutsou, M., Bacher, S., Chiron, F., Didžiulis, V., Essl, F., Genovesi, P., 2010. Disentangling the role of environmental and human pressures on biological invasions across Europe. Proc. Nat. Acad. Sci. USA 107, 12157-12162.

Redman, C.L., Grove, J.M., Kuby, L.H., 2004. Integrating social science into the long-term ecological research (LTER) network: social dimensions of ecological change and ecological dimensions of social change. Ecosystems 7, 161-171.

Reed, M.S., Evely, A., Cundill, G., Fazey, I., Glass, J., Laing, A., Newig, J., Parrish, B., Prell, C., Raymond, C., Stringer, L., 2010. What is social learning? Ecol. Soc. 15.

Reed, M.S., Vella, S., Sidoli del Ceno, J., Neumann, R.K., de Vente, J., Challier, S., Frewer, L., van Delden, 2017. A theory of participation: what makes stakeholder engagement and public engagement in environmental management work? Restor. Ecol. 26, S7-S17. https://doi.org/10.1111/rec.12541.

Ricciardi, A., Blackburn, T.M., Carlton, J.T., Dick, J.T., Hulme, P.E., Iacarella, J.C., Jeschke, J.M., Liebhold, A.M., Lockwood, J.L., MacIsaac, H.J., Pyšek, P., Richardson, D.M., Ruiz, G.M., Simberloff, D., Sutherland, W.J., Wardle, D.A., Aldridge, D.C., 2017. Invasion science: a horizon scan of emerging challenges and opportunities. Trends Ecol. Evol. 32, 464-474.

Richardson, D.M., 2011. Invasion science: the roads travelled and the roads ahead. In: Richardson, D.M. (Ed.), Fifty Years of Invasion Ecology. The Legacy of Charles Elton. Wiley-Blackwell, Oxford, pp. 397-407.

Richardson, D.M., Ricciardi, A., 2013. Misleading criticisms of invasion science: a field guide. Divers. Distrib. 19, 146101467.

Richardson, D.M., Pyšek, P., Rejmánek, M., Barbour, M.G., Panetta, F.D., West, C.J., 2000. Naturalization and invasion of alien plants: concepts and definitions. Divers. Distrib. 6 93-07.

Richardson, D., Pyšek, P., Simberloff, D., Rejmánek, M., Mader, A., 2008. Biological invasions-the widening debate: a response to Charles Warren. Prog. Hum. Geogr. 32, 295. 
Richardson, D.M., Pyšek, P., Carlton, J.T., 2011. A compendium of essential concepts and terminology in invasion ecology. In: Richardson, D.M. (Ed.), Fifty Years of Invasion Ecology. The Legacy of Charles Elton. Wiley-Blackwell, Oxford, pp. 409-420.

Robbins, P., 2001. Tracking invasive land covers in India, or why our landscapes have never been modern. Ann. Assoc. Am. Geogr. 91, 637-659.

Robbins, P., 2004a. Comparing invasive networks: cultural and political biographies of invasive species. Geogr. Rev. 94, 139-156.

Robbins, P., 2004b. Culture and politics of invasive species. Geogr. Rev. 94, 3-4.

Rotherham, I.D., Lambert, R.A., 2011. Invasive and Introduced Plants and Animals: Human Perceptions, Attitudes and Approaches to Management. Earthscan, London and Washington DC.

Ruiz, G.M., Carlton, J.T., 2003. Invasive Species. Vectors and Management Strategies. Island Press, Washington, D.C.

Russel, J.C., Blackburn, T.M., 2017. The rise of invasive species denialism. Trends Ecol. Evol. 32, 3-6.

Shackleton, C.M., McGarry, D., Fourie, S., Gambiza, J., Shackleton, S.E., Fabricius, C. 2007. Assessing the effects of invasive alien species on rural livelihoods: case examples and a framework from South Africa. Hum. Ecol. 35, 113-127.

Shackleton, R.T., Le Maitre, D.C., van Wilgen, B.W., Richardson, D.M., 2016. Identifying barriers to effective management of widespread invasive alien trees: Prosopis species (mesquite) in South Africa as a case study. Global Environ. Change 38, 183-194.

Shackleton, R.T., Witt, A.B., Aool, W., Pratt, C.F., 2017. Distribution of the invasive alien weed, Lantana camara, and its ecological and livelihood impacts in eastern Africa. Afr. J. Range Forage Sci. 34, 1-11.

Shackleton, R.T., Richardson, D.M., Shackleton, C.M., Bennet, B., Crowley, S., DehnenSchmutz, K., Estévez, R., Fisher, A., Kueffer, C., Kull, C.A., Marchante, E., Novoa, A Potgieter, L.J., Vaas, J. Vaz, A.S., Larson, B.M.H., in this issue a. Explaining people's perceptions of invasive alien species: a conceptual framework. J. Environ. Manag.. https://doi.org/10.1016/j.jenvman.2018.04.045.

Shackleton, R.T., Shackleton, C.M., Kull, C. A., in this issue b. The role of invasive alien species in shaping local livelihoods and human well-being. J. Environ. Manag. https://doi.org/10.1016/j.jenvman.2018.05.007.

Shackleton, R.T., Adriaens, T., Brundu, G., Dehnen-Schmutz, K., Estevez, R., Fried, J., Larson, B.M.H., Lui, S., Marchante, E., Marchante, H., Moshobane, M., Novoa, A., Reed, M., Richardson, D.M., this issue c. Stakeholder engagement in the study and management of invasive alien species: a review. J. Environ. Manag.. https://doi.org/ 10.1016/j.jenvman.2018.04.044.

Shrestha, B.B., Shrestha, U.B., Sharma, K.P., Thapaparajuli, R.B., Devkota, A., Siwakoti, $\mathrm{M}$., in this issue. Community perception and prioritization of invasive alien plants in Chitwan-Annapurna Landscape, Nepal. J. Environ. Manag.. https://doi.org/10.1016/ j.jenvman.2018.06.034.

Stokes, K.E., O'Neill, K.P., Montgomery, W.I., Dick, J.T.A., Maggs, C.A., McDonald, R.A., 2006. The importance of stakeholder engagement in invasive species management: a cross-jurisdictional perspective in Ireland. Biodivers. Conserv. 15, 2829-2852.

Symanski, R., 1994. Contested realities: feral horses in Outback Australia. Ann. Assoc. Am. Geogr 84, 251-269.

Teel, T.L., Anderson, C.B., Burgman, M.A., Cinner, J., Clark, D., Estévez, R.A., Jones, J.P., McClanahan, T.R., Reed, M.S., Sandbrook, C., John, F.A., 2018. Publishing social science research in Conservation Biology to move beyond biology. Conserv. Biol. $32,6-8$.

Thomas, W.L., 1956. Man's Role in Changing the Face of the Earth. University of Chicago Press, Chicago.

Thuiller, W., Richardson, D.M., Rouget, M., Procheş, Ş., Wilson, J.R.U., 2006. Interactions between environment, species traits, and human uses describe patterns of plant invasions. Ecology 87, 1755-1769.

Turner, B.L., Esler, K.J., Bridgewater, P., Tewksbury, J., Sitas, N.J., Abrahams, B., Stuart Chapin II, F., Chowdhury, R.R., Christie, P., Diaz, S., Firth, P., Knapp, C.N., Kramer, J., Leemasn, R., Palmer, M., Pietri, D., Pittman, J., Sarukhán, J., Shackleton, R., Seilder, R., van Wilgen, B., Mooney, H., 2016. Socio-Environmental Systems (SES) Research: what have we learned and how can we use this information in future research programs. Curr. Opin. Environ. Sustain. 19, 160-168.

Udo, N., Darrot, C., Atlan, A., in this issue. From useful to invasive, the status of gorse on Reunion Island. J. Environ. Manag.. https://doi.org/10.1016/j.jenvman.2018.06. 036.

Van Wilgen, B.W., Richardson, D.M., 2012. Three centuries of managing introduced conifers in South Africa: benefits, impacts, changing perceptions and conflict resolution. J. Environ. Manag. 106, 56-68.

Van Wilgen, B.W., Dyer, C., Hoffmann, J.H., Ivey, P., Le Maitre, D.C., Moore, J.L. Richardson, D.M., Rouget, M., Wannenburgh, A., Wilson, J.R.U., 2011. National-scale strategic approaches for managing introduced plants: insights from Australian acacias in South Africa. Divers. Distrib. 17, 1060-1075.

Vaz, A.S., Kueffer, C., Kull, C.A., Richardson, D.M., Schindler, S., Muñoz-Pajares, Vicente, J.R., Martins, J., Hui, C., Kühn, I., Honrado, J.P., 2017a. The progress of interdisciplinary in invasion science. Ambio 46, 428-442.

Vaz, A.S., Kueffer, C., Kull, C.A., Richardson, D.M., Vicente, J.R., Kühn, I., Schröter, M., Hauck, J., Bonn, A., Honrado, J.P., 2017b. Integrating ecosystem services and disservices: insights from plant invasions. Ecosyst. Serv. 23, 94-107.

Villatoro, F.J., Naughton-Treves, L., Sepúlveda, M., Stowhas, P., Mardones, F., SilvaRodríguez, E.A., in this issue. When free-ranging dogs threaten wildlife: public attitudes toward management strategies in southern Chile. J. Environ. Manag.. https:// doi.org/10.1016/j.jenvman.2018.06.035.

Wald, D.M., Nelson, K.A., Gawel, A.M., Rogers, H.S., in this issue. The role of trust in public attitudes towards invasive species management on Guam: a case study. J. Environ. Manag.. https://doi.org/10.1016/j.jenvman.2018.06.047.

Warren, C.R., 2007. Perspectives on the 'alien' versus 'native' species debate: a critique of concepts, language and practice. Prog. Hum. Geogr. 31, 427-446.

Warren, C.R., 2009. Using the native/alien classification for description not prescription: a response to Christopher Preston. Prog. Hum. Geogr. 33, 711-713.

Wilson, J.R.U., Dormontt, E.E., Prentis, P.J., Lowe, A.J., Richardson, D.M., 2009. Something in the way you move: dispersal pathways affect invasion success. Trends Ecol. Evol. 24, 36-144.

Wilson, J.R.U., García -Díaz, P., Cassey, P., Richardson, D.M., Pyšek, P., Blackburn, T.M., 2016. Biological invasions and natural colonisations are different- the need for invasion science. NeoBiota 31, 87-98.

Woodford, D.J., Richardson, D.M., MacIsaac, H.J., Mandrak, N.E., van Wilgen, B.W. Wilson, J.R.U., Weyl, O.L.F., 2016. Confronting the wicked problem of managing biological invasions. NeoBiota 31, 63-86. https://doi.org/10.3897/neobiota.31. 10038.

Zengeya, T., Ivey, P., Woodford, D.J., Weyl, O., Novoa, A., Shackleton, R., Richardson, D., van Wilgen, B., 2017. Managing conflict-generating invasive species in South Africa: challenges and trade-offs. Bothalia 47 (2), a2160. https://doi.org/10.4102/abc. v47i2.2160.

Zimmermann, H., Brandt, P., Fischer, J., Welk, E., von Wehrden, H., 2014. The Human Release Hypothesis for biological invasions: human activity as a determinant of the abundance of invasive plant species. F1000Research 3, 109.

Ross T. Shackleton

Institute of Geography and Sustainability, University of Lausanne, 1015, Lausanne, Switzerland

E-mail address: rtshackleton@gmail.com (R.T. Shackleton)

Brendon M.H. Larson

School of Environment, Resources and Sustainability, University of Waterloo, Waterloo, Ontario, N2L3G1, Canada

Ana Novoa

Institute of Botany, Department of Invasion Ecology, The Czech Academy of Sciences, CZ-252 43, Průhonice, Czech Republic

David M. Richardson

Centre for Invasion Biology, Department of Botany and Zoology, Stellenbosch University, Matieland, 7602, South Africa

Christian A. Kull

Institute of Geography and Sustainability, University of Lausanne, 1015, Lausanne, Switzerland

${ }^{*}$ Corresponding author. 